\title{
Author Correction: Evidence for a serpentinized plate interface favouring continental subduction
}

\author{
Liang Zhao (D), Marco G. Malusà (1), Huaiyu Yuan (D), Anne Paul (D), Stéphane Guillot, Yang Lu, Laurent Stehly, \\ Stefano Solarino (1), Elena Eva, Gang Lu, Thomas Bodin, CIFALPS Group \& AlpArray Working Group
}

Correction to: Nature Communications https://doi.org/10.1038/s41467-020-15904-7, published online 1 May 2020.

The original version of this article contained an error in Figure 1, in which the heading of panel (c) was mislabelled as ' $40 \mathrm{~km}$ '. The correct heading of panel (c) is ' $50 \mathrm{~km}$ '. The caption of Figure 1 also contained the same error. Both the panel heading and caption of Figure 1 have now been corrected in the PDF and HTML versions of the article.

Published online: 28 July 2020

\begin{abstract}
(c) (i) Open Access This article is licensed under a Creative Commons Attribution 4.0 International License, which permits use, sharing, adaptation, distribution and reproduction in any medium or format, as long as you give appropriate credit to the original author(s) and the source, provide a link to the Creative Commons license, and indicate if changes were made. The images or other third party material in this article are included in the article's Creative Commons license, unless indicated otherwise in a credit line to the material. If material is not included in the article's Creative Commons license and your intended use is not permitted by statutory regulation or exceeds the permitted use, you will need to obtain permission directly from the copyright holder. To view a copy of this license, visit http://creativecommons.org/licenses/by/4.0/.
\end{abstract}

() The Author(s) 2020 